\title{
Beyond geopower: earthly and anthropic geopolitics in The Great Game by War Boutique
}

\begin{abstract}
This article reconsiders the nature of art and geopolitics and their interrelations via a discussion of The Great Game, an artwork by War Boutique dealing with successive British military interventions in Afghanistan. As we discuss, The Great Game is richly suggestive in terms of the earthly materials and forces at work in geopolitics, as well as the roles played by objects and technology. The main goal of our discussion, however, is to show how pursuing such concerns leads us back towards a consideration of the ideational, the human and the representational and the roles they play in art and in geopolitics. We argue that framing art in terms of the earthly, the affective and the inhuman is suggestive but misses too much of what art is otherwise taken to be and to do, sometimes even within accounts framed in earthly terms. Because we are initially responding to the work rather than seeking to explicate it, we first provide an extended discussion of the The Great Game, in which we consider how it entangles earthly and anthropic dimensions of geopolitics. We then bring this discussion back to bear on academic work that rethinks geopolitics and art in earthly, inhuman, nonrepresentational and affective terms. Third, we discuss how our understanding of art and geopolitics is enhanced by reflection on what makes artistic engagements with geopolitics artistic, considering how The Great Game has moved through a series of artworlds. In conclusion, we underscore the extent to which art is suggestive as an onto-epistemological form of inquiry into geopolitics as well as an aesthetic-political practice with regard to it.
\end{abstract}

\section{Introduction}

As geographical interest in art continues to flourish and diversify, a growing body of work considers the interrelations of art and geopolitics. Within this work a number of intersecting conceptual and analytical approaches can be identified. Some of these are critical, in that they consider art in terms of revelatory, resistant or disruptive potential with regard to geopolitics. Others address the possibilities of experimentation, play and performativity, while themes of embodiment, technology and the role of objects have also been explored. While often concerned with questions of representation, and working through ideas of art and geopolitics in which human practices, subjectivities and collectives loom large, much of this literature at the same time figures art and geopolitics (more or less explicitly and to a greater or lesser extent) as more-than-human and more-than-representational. ${ }^{1}$ A somewhat distinct line of inquiry, meanwhile, realised in and inspired by the work of 
Elizabeth Grosz, seeks to push understandings of art and geopolitics much further beyond the anthropic and the representational. Locating art at an ontological level as a manifestation of earthly and inhuman powers of chaos, differentiation and creativity, or geopower, this work advances a significantly reframed take on geopolitics, art and their inter-relation. ${ }^{2}$

In this article we aim to further conversations about the nature and mutual entanglement of art and geopolitics via a consideration of an artwork The Great Game by War Boutique - that prompts us to think across and to question these lines of inquiry. This artwork, which deals with successive British military interventions in Afghanistan, emerges from and is directed towards episodes of organised violence between human political collectives (the preoccupation of much critical work on art and geopolitics), but also calls our attention to the material dimensions and circumstances of such encounters by the manner in which it incorporates earthly materials. ${ }^{3}$ Particularly relevant is how the work uses camouflage, an earthly aesthetic technology that is widely employed among nonhuman species but is also appropriated and adapted for a variety of purposes in human art, war, fashion and commerce. We explore the materiality and representivity of camouflage and other aspects of the work and consider how the materials that it involves have been appropriated and fabricated across military and artistic spheres in ways that are both creative and critical, strategic and artistic. As we aim to show, while it has been fabricated from a situated and partial position, The Great Game is richly suggestive in terms of the earthly materials and forces at work in geopolitics, as well as the roles played by technology and objects.

While our discussion is therefore to a significant extent in sync with moves towards questions of the material, the inhuman and nonrepresentational, our main goal is to show how a pursuit of these ideas leads us back towards questions of the ideational, the human and the representational and the roles they play in art and in geopolitics. In particular, we wish to show how the dualistic nonrepresentational/representational condition of art highlights a more general problematic in the interplay between mind, body and world, one that has been central to debates in art, aesthetics and philosophy more generally and which is not captured effectively in terms of geopower. Our specific argument is that while some ontolotically-oriented work aims to subsume or subordinate the human within the natural and the representational within the affective, ${ }^{4}$ this leaves us unable to account for important aspects of what are frequently taken to be the artistic and the geopolitical. Accounts framed as more-than-representational or more-than- 
human, meanwhile, we suggest, also imply a continuing need to account for what is specifically representational or human. ${ }^{5}$

To develop this argument, we focus particularly on something that has often remained implicit or under-developed: the question of the 'artness' or ontology of art and how this figures in its relation with the geopolitical.

Following a line of argument well established in art history, we suggest that art involves a constitutive duality between the nonrepresentational and the representational, between 'isness' and 'aboutness'. ${ }^{6}$ Furthermore, the capacity to apprehend this duality (as well as to conceptualise it and to set it in motion via the creation of art works) requires perceptual, cognitive and creative abilities that appear to be distinctive to humans. ${ }^{7}$ We further suggest that art becomes legible ${ }^{8}$ as a distinct category of practice and experience defined by artworks, artists and art institutions in specific historical, geographical and social circumstances, that is, in relation to what Danto called an artworld. ${ }^{9}$

Our line of argument differs somewhat from recent efforts to bring together earthly, critical, feminist and postcolonial approaches to geopolitics through a consideration of art. In this regard Angela Last has argued that dominant forms of geopolitics are called into question by postcolonial literature that begins with the disruptive and creative forces of the earth. In this argument, a poetics of geophysical phenomena (such as extreme climatic events) that transcend political borders and collectives becomes 'a tool for resituating oneself and reimagining global divisions'. ${ }^{10}$ While we also consider how artworks simultaneously instantiate the earthly and the critical, we are less concerned with their possible ethical or political import than the questions of what it is that makes them art in the first place and what the implications of this are for our understanding of geopolitics.

We argue that framing art in terms of the earthly, the affective and the inhuman is thus suggestive but misses too much of what 'art' is otherwise taken to be and to do, sometimes even within accounts framed in earthly terms. While art may appear to enable us to resituate ourselves within the natural, the material or the earthly, or to express the creativity of inhuman forces and actors, it does so via capacities that enable us to represent, to manipulate, to communicate and to act socially in ways that are more highly developed in humans than other species. The relevance of this for geopolitics is that it is by virtue of these same capacities that humans have also been able to transform nature, materiality and the earth in ways that give rise to geopolitical phenomena, including domination over other species. ${ }^{11}$

In methodological terms, and illustrative of the kinds of 'dialogues and doings ${ }^{12}$ taking place between art and geography, the article emerges out of 
our involvement with artistic, curatorial and research practices on the one hand and art objects, contexts and events on the other. In writing the article we draw, first, on academic research into contemporary and historical forms of geopolitics involving the British military as well as how these instances of geopolitics have been materialized and represented in art. Second, we draw on the experience of one of us in having curated The Great Game as part of a recent major exhibition on art, war and peace in a public institution in the UK. Third, we draw on a discussion and viewing of the artwork itself in the artist's studio; as shown within the public exhibition; and at a temporary exhibition at the Royal Geographical Society in London. Our discussion is further informed by an interview and ongoing conversations with the artist. Finally, the article draws substantially on an artist essay intended to accompany the work, which discusses its form and content and relates it to aspects of geopolitics. ${ }^{13}$ While not denying that this can be significant and for some, a primary concern, our argument only touches on the question of the artwork's reception among viewers and audiences beyond ourselves, and then only within artworld contexts. Rather, we respond to the artwork as issuing 'invitations to thought ${ }^{14}$ concerning how we might conceive of art, geopolitics and their interrelation.

Our discussion is developed in three stages. Because we are initially responding to the work rather than seeking to explicate it, we first provide an extended discussion of the The Great Game, in which we consider how it entangles earthly and anthropic dimensions of geopolitics. We then bring this discussion back to bear on some of the academic work that rethinks geopolitics and art in earthly, inhuman and affective terms. Third, we discuss how our understanding of art and geopolitics is enhanced by reflection on what makes artistic engagements with geopolitics artistic, considering how The Great Game has moved through a series of artworlds. In conclusion, we underscore the extent to which art is suggestive as a onto-epistemological form of inquiry into geopolitics as well as an aesthetic-political practice with regard to it and consider some of the broader stakes of the discussion.

\section{The Great Game by War Boutique}

War Boutique is the working name for a British artist whose practice focuses on the use of requisitioned and recycled textiles, uniforms and other military and ballistic materials to create objects that examine the nature of war, the politics of security and their relationship with economic interests. This practice reflects an engagement with contemporary geopolitical issues that is attuned to questions of materiality and embodiment, while maintaining a sceptical stance towards the political interests and investments that continue to drive 
geopolitical violence and security agendas. Grounded in professional expertise gained through degree-level training in textiles and a career in the design of high-specification military and police uniforms and equipment, War Boutique repurposes materials taken from a wide variety of geopolitical situations towards a questioning of the political, economic and cultural interests involved in violent conflict and of what it might mean to act in a more peaceful manner. ${ }^{15}$

Uniforms, clothing and protective equipment have been a recurring focus of War Boutique's practice, which has resulted in the creation of works such as Guff War II, a British military desert camouflage ballistic vest and helmet accessorised with remembrance poppy, BP logo and 'BLAIR T.' name badge and City Gent Soldier, a bulletproof suit tailored from high quality Gieves and Hawkes chalk stripe worsted wool, accessorised with urban conflict equipment (Figures 1 and 2).

\section{[INSERT FIGURES 1 AND 2 HERE]}

Reworking preoccupations with fashion, militarism and violence in relation to ongoing events, War Boutique's appropriation of clothing and protective equipment highlights the differential constitution of (mostly) human bodies in contemporary conflict and points up their emergence and entanglement within a wide variety of geopolitical assemblages.

Among War Boutique's work, The Great Game (Figure 3) is particularly relevant to earthly and anthropic accounts of geopolitics because of the ways in which it goes beyond the specifically human to entangle the material and environmental with the imperial and strategic.

\section{[INSERT FIGURE 3 ABOUT HERE]}

The Great Game is composed of sections of British military fabrics shaped to spell out the title of the work, stitched onto an Afghan keffiyeh, in turn layered over a goat hair chador (or patu) blanket and mounted using a yurt tent pole. The work highlights the point that, as an interface between body and environment, solider and state, militarised clothing reflects both the immersion of the human within the earthly and the effort to achieve mastery through its control.

Relevant considerations in the design of military clothing include the envisaged terrain, vegetation, climatic and weather conditions within which it will be worn, but also changing tactics and weapons, innovations in textile 
production and shifts in cultural norms. Changes in uniform and battle dress are also bound up with hierarchies of rank and the formation of group identities, as well as the need to accommodate a continually evolving assemblage of technological objects, including optical, medical, communications, ammunition, navigation, timekeeping and recording devices. Military clothing thus both materialises and participates in wider transformations in the inter-relations between human communities and their physical and technological environments. Military clothing and camouflage therefore provide a potentially rich entry point into multiple dimensions of geopolitics, ranging from questions of tactics and strategy to the human involvement with and appropriation of nature, while the contrast between British and Afghan fabrics alludes to asymmetric imperial entanglements.

The work is interesting to us to a large extent because of its complex ontological status. It is an object fabricated from natural and synthetic materials that have been derived from the earth, but with strategic and tactical considerations in mind. Created from military materials and alluding to political as well as visual camouflage, The Great Game is premised upon the importance of deception in military affairs, yet as an art work it invites visual engagement, as well as cognitive attention and intellectual reflection. The object could function as a blanket, but one that has a genealogy that is reflexively highlighted in its execution and presentation as art. The work 'is' 'art' and 'geopolitics' and 'about' them.

The entanglement of fabrics and clothing in networks of imperial violence, traffic and trade is signalled by War Boutique at an early stage in the essay that accompanies the work and which also signals the British location and vantage point from which it has been fabricated:

This multi-layered tapestry explores what fabrics can tell us about the history and motivations of our recurring military involvement in Afghanistan, and the impact of this on a landscape, culture and people. It also references how the fine cloths being produced in the Indian sub-continent were one of the primary exports of the East India Company, and the commercial value of these fabrics was one of the main reasons that the British needed to secure the trade route through Afghanistan in the first place. ${ }^{16}$

Utilising fabrics from each of the major British interventions in Afghanistan (known in Britain as the First Anglo-Afghan War, 1839-1842, The Second Anglo-Afghan War, 1878-1880 and the most recent involvement, termed Operation Herrick by the British military, 2001-2014), The Great Game links together and reconfigures these geopolitical events. 
In using carefully chosen fabrics, the work draws attention to shifting forms of political, military and corporate organisation. The first British Afghan intervention was conducted not by 'the state' but by units of the East India Company, which had become deeply interested in Afghanistan as a zone of strategic concern between the Russian and British empires and which drew many of its troops from India. As described by War Boutique, the Company, an 'enterprising group of extremely wealthy traders',

brought tea, coffee, spices, cloth and other goods from the Empire through Afghanistan's narrow valleys, often at gunpoint. It was considered important for investors to see their goods flow through to market quickly and efficiently, regardless of the cost to human life. ${ }^{17}$

As an artwork, The Great Game is thus implicated in the commercial as well as military imperatives of empire. But it also reflects the shifting environmental and strategic considerations influencing military practices in Afghanistan and beyond. It reminds us of how, as Guy Hartcup has documented, in the midnineteenth century, technology and science began to transform the character of warfare, in particular through the development of firearms, which led to weapons becoming more accurate and gaining the capacity to operate over longer ranges. ${ }^{18}$ It therefore became necessary to conceal soldiers in order to reduce casualties, and camouflage technology evolved through the enrolment of the body, materiality and aesthetics in response to technological innovations in observation and targeting.

The sequence of innovations in fabrics and patterning is reflected in how The Great Game is constructed. The first word, THE, is spelled out using dyed fabrics that are derived from animals (scarlet red wool barathea, blue-black wool barathea and rifle green wool barathea) and whose history dates from the first Anglo-Afghan War. These fabrics were sourced by the artist via research in the archives of Gieves and Hawkes (a company that currently occupies the former home of the Royal Geographical Society at 1 Savile Row, London). But these uniforms were in certain key respects ill-suited to Afghan surroundings. Woollen tunics were 'susceptible to overheating' in the summer and the bright red fabric crossed with white leather straps formed 'a clear target against the backdrop of the desert soil or mountainous scrub'.

By the time of the Second Anglo-Afghan War, the Company's units had been incorporated into the British Army 'and the changing fabric of their dress reflected new methods of engagement'. Coloured wool uniforms had been replaced by 'much cooler and lighter coloured white cotton drill fabric...', but '[a]lthough the cotton was found to be a much superior fabric in terms of sweat management, the colour still stood out against the sandy desert 
conditions, making concealment again rather difficult'. So while this signals the importance of the textiles themselves in mediating the relationship between body, terrain and climate, it is also where camouflage, a means of modifying the relationship between terrain, bodies and visuality, begins to become significant. As War Boutique notes,

Officers observed that soldiers coming back from patrol covered in soil and vegetation stains from guerrilla tactics and concealment in the field were much better camouflaged against their surroundings than their colleagues in clean white uniforms.

British imperial soldiers, 'ordered to field-dye their uniforms using whatever means were available to them', turned to the tea and coffee whose trade they were in significant part there to protect, contributing to the development of 'khaki' (from the Urdu word meaning 'dust', 'dirt' or 'mud') colouring.

The second word, GREAT, is accordingly spelled out in white cotton drill, field-dyed by the artist with tea and coffee, khaki drill woollen and cotton fabric. As well as climatic considerations, the shift from wool to cotton further registers the changing geographies of the industrial revolution and the politicaleconomic calculations of the British empire; while specialisation in woollen fabrics developed in East Anglia, West Country, the Pennines and the Scottish Borders, the rise of the cotton industry in the growing urban centres of Lancashire was premised on the suppression of Indian manufacturers.

Military camouflage designs and practices continued to shift through the First and Second World Wars, where advancements in the technology of the aeroplane as bomber and instrument of surveillance led camouflage to become enrolled in a game of cat and mouse between the aerial observer and bomber, and the grounded camouflage deceiver. ${ }^{19}$ Phases of camouflage innovation came in waves, some more successful and practical than others, but each altering the aesthetics and materialities not just of uniform but the battlefield itself; concealing netting and scrimming were superseded by deceiving dummies and decoys. Through both scientific efforts and the artistic eye, Camouflage Officers replicated the pigments and patterns of nature with human-made paints and materials not just on uniforms but on human-made weapons and infrastructure too. ${ }^{20}$ Animal aesthetics - notably, disruptive patterning and countershading - were thus appropriated and militarised via artistic and scientific practices.

The word GAME registers post-Second World War advances in camouflage technology, notably the evolution of disruptive patterning for different terrains: in desert three-colour $(\mathrm{G})$, woodland four-colour $(\mathrm{A})$ and desert two-colour disruptive patterning $(\mathrm{M})$ and in fabrics, with a move into more durable synthetic-natural material. The final letter $(\mathrm{E})$ is composed of 
polycotton (a hybrid fabric manufactured in China, a further shift in industrial geography) designed with the latest 'multi-terrain pattern' (MTP), which was introduced in March 2010 and licensed initially for military use only (in this regard the work technically breaches the military's control over such patterns).

The creation of MTP, the first new general issue camouflage to be adopted by the British military in forty years, was itself the result of an extensive research and development process that further reflects the entangled relations between the military, the technological and the environmental and the continuing role in them of experimental and creative practices. We note that, created in response to an Urgent Operational Requirement for a pattern that would meet the particular requirements of the 'Afghan theatre', MTP (the successor to No.08 Disruptive Pattern Material, DPM) was developed through field observations in Afghanistan, experimental testing in the UK, computer modelling and consultations with soldiers. As Bob Ainsworth, then Secretary of Defence, stated,

This new camouflage will help our troops blend into different environments in Helmand Province to stay hidden from the Taliban... Patrols take our troops through the Green Zone, scrubland, desert and arid stony environments and it is crucial that the camouflage can work across all of them. ${ }^{21}$

We can also observe how climate and terrain are important contributors to conflict in Afghanistan in other ways too. The cultivation of opium poppies, to which parts of Afghanistan are exceptionally well suited, begins with planting in December and culminates with harvest in spring, with attacks on coalition forces often spiking afterwards. Indeed, the Taliban have often announced a 'spring offensive' around this time, a ritual that accompanies the onset of what is commonly referred to as 'fighting season'. To conceal their identities, blend in with local populations and cope with climatic conditions that can range from sub-zero to over 30 degrees in a day, insurgent fighters (and often Western special forces troops seeking to mimic them) adopt keffiyeh headscarves (also known as shemagh or dismaal) and blankets (chador or patu) of the kind included in The Great Game, which can be adapted to conditions as necessary.

The work further alludes, both chromatically and semantically, to the transformation of Afghan terrain through military violence and its biogeographical 'blowback'. War Boutique describes how blast wave disruption of soil by carpet bombing in the early phases of Western military intervention led to significantly increased yields of opium poppies, 'an outcome first discovered on the battlefields of Belgium and northern France in the aftermath of the First World War'. As a consequence, '[t]he red fabric of the early British 
uniforms in the piece recalls the bright splashes of colour that today's crops make against the beige coloured earth of the region'.22 But the time-space of the work is not just Britain in Afghanistan and Afghanistan in Britain - it is also Britain in France and Belgium of 1914-1918 and France and Belgium in British practices of remembrance within the UK, which now again include remembrance of losses in Afghanistan.

In many ways, then, The Great Game points towards an understanding of geopolitics as being carried forward by materials, technologies, processes and forces that interconnect terrain, climate, agriculture, political economy, culture, logistics, crime and addiction between widely dispersed places. It embodies and implies forces that act, as John Protevi suggests, above, below and alongside subjectivity as well as through it. ${ }^{23}$ But the work is also textual and critical in ways that would be missed by a resolutely nonrepresentational account. The most recent British intervention in Afghanistan has been characterised by a series of shifting narratives and discourses, with counter-terrorism, the emancipation of women, democratisation, nation-building, drug control and the geopolitics of oil and mineral resources all surfacing as stated or imputed reasons for the British military presence. Here, for War Boutique, the title of the work, which can be traced to a phrased used in correspondence between British Political Officers Captain Arthur Connolly and Henry C. Rawlinson in the late 1830 s, becomes particularly pertinent. ${ }^{24}$ If the phrase 'the great game' originally referred with enthusiasm to a putative civilising mission in Central Asia, it later came to signify both the activities of Russian and British spies and envoys and the broader rivalry between the two empires. Today, in the work, the phrase is decidedly ambiguous, conveying no little irony towards foreign military intervention and the political, economic and institutional interests supporting it.

Text and camouflage, semantics and chromatics thus refer to and play off each other in the work. Indeed, as a British officer during the Second World War averred: 'I think you will now have realised that the curious work of "Camouflage" covers a wide field of military activity. There is a voodoo quality about the word'. ${ }^{25}$ In this vein, the work perhaps asks what might be obscured in public understanding of geopolitics today? War Boutique suggests that with the development of drones, the trajectory of Western war is now towards the absence of human military bodies from the landscape altogether, 'from the startlingly open and obvious, to a game of camouflage and subterfuge, and finally, to complete invisibility'. ${ }^{26}$

\section{Geopolitics earthly and anthropic}


The Great Game contains a recognisable critique of geopolitics: that it is driven by the machinations of vested interests, by capitalism, imperialism and militarism, the nature and operation of which are obscured from non-elite observers. ${ }^{27}$ To a significant extent, then, we might term its concerns anthropic. But it also embraces the material and the earthly, interest in which has been growing across the social sciences and humanities for more than a decade and which have more recently started to be worked through specifically in relation to geopolitics both within and beyond political and cultural geography.

This working through has taken several forms. ${ }^{28}$ Of particular relevance to our discussion are Manuel De Landa's conceptualisation of 'nonlinear history' in terms of flows of matter and energy ${ }^{29}$ and conversations on art and geopolitics around the work of Elizabeth Grosz, who rethinks geopower and art in terms of inhuman forces that give rise to life through ceaseless processes of differentiation. ${ }^{30}$ For Grosz, art emerges from geopower,

from the provocations posed by the forces of the earth (cosmological forces that we can understand as chaos, material and organic indeterminacy) with the forces of living bodies, by no means exclusively human, which exert their energy or force through the production of the new and create, through their efforts, networks, fields, territories that temporarily and provisionally slow down chaos enough to extract from it something not so much useful as intensifying, a performance, a refrain, an organization of colour or movement that eventually, transformed, enables and induces art. ${ }^{31}$

In Grosz's account, processes of actualization slow down and territorialise chaotic forces as rocks, plants or animal life, which intensify and exert sensations that affect bodies both human and nonhuman, even as they are ceaselessly being undone by processes of differentiation. De Landa meanwhile proceeds from a related (that is, Deleuzian), ontological starting point, with the goal of explicating how a 'single matter-energy' undergoes bifurcations, phase transitions and combinatorics, giving rise to such diverse entities as 'rocks and winds, germs and words'. ${ }^{32}$ For De Landa, the living and the nonliving ought to be explicable within a single 'geological' framework, where the kinds of historical processes giving rise to mountains also give rise to cities and languages.

As points of inspiration for rethinking geopolitics, Grosz and De Landa both see specific materials, objects and events as the actualisation of becomings, temporalities and processes, ceaseless processes of proliferation and differentiation. Bringing such ideas into our response to The Great Game, we might be drawn towards rocky, dusty terrain and its brown, beige and khaki 
colours; opium and the red of poppies; the wool of animals; the wooden pole; and to cotton, tea and coffee plants. Furthermore, each of these has specific kinds of durations, intensities and sensations: the geological timescales of Afghanistan's mountainous terrain and climate, the seasonality of opium and its effects on the human body in unrefined and refined forms, all of which loom large in recent geopolitics. The Great Game thus entails multiple nonhuman components that are 'nonlocal' in time and space and which do not sit within politically defined territories or individual human bodies, but which work within and through them, undoing them as well as being mobilised by them. ${ }^{33}$

While this line of thinking certainly expands and reframes our sense of the geopolitical, it only gets us so far in terms of our response. Here we note a comment made by Grosz on a panel discussing her work that,

for me this [the idea of geopower] is about politics, but it's about politics three steps before we can really think about politics, so it's about the raw material, the forces, of politics and the ontological conditions under which politics can emerge, forces of the earth, forces of things, forces of living beings. ${ }^{34}$

What is intriguing here are the different ideas of 'politics' that are being invoked. There is an onto-politics of forces, earthliness and life before (as well as within, above and beyond) the other kind of politics, with (at least) three steps between them. As Nigel Clark argues, Grosz calls attention to 'the more intractable forces of earth and cosmos', which are simply not amenable to anthropic negotiation and remaking. ${ }^{35}$ This onto-politics is also argued to hold productive possibilities with regard to more anthropic forms. Following Darwin, Grosz argues for the primacy of sexual selection (and thus, seduction, love and the erotic) over natural selection in life's becoming. As Clark argues, this is welcome in that this generative power 'comes with a spatial imaginary that refuses the primacy of antagonism and conflict'. ${ }^{36}$ Grosz's account of ontology thus comes with an ethical and political bonus with regard to conventional accounts of evolution and politics. Thus,

By treating the 'geo' as a power, an incitement, a generative force, Grosz offers an alternative to those 'critical' modes of geopolitics whose investments in contested terrains and struggles over scarce resources often partake of the same restricted economies as their adversaries. ${ }^{37}$

According to this line of argument, 'critical' takes on geopolitics tend to miss what is not human or humanly contestable and remain trapped within the frames of antagonism and struggle.

Two interesting issues arise here. The first lies in tying art as geopower to sexual selection. Drawing on Darwin and Deleuze, Grosz uses the term art to refer to 'all forms of creativity or production that generate intensity, 
sensation or affect ${ }^{38}$ Emerging from display, desire and attraction, art territorialises by intensifying sensations through the refrain. But camouflage is intriguing here, because it is defined by the non-production of sensation and affect; it is a form of creativity and production that depends on not intensifying, on generating no affect or percept. Does this mean that it is not, therefore, art? This would seem strange, given its aesthetic function. Furthermore, if camouflage is associated (as it appears to be) with predation and survival rather than sex and desire, this would appear to link it with domination and struggle. Camouflage might itself thus complicate the positivity of Grosz's account of geopower, art and territory, within in its own terms.

A second issue is whether, once our sense of geopolitics has been expanded to the earthly and the cosmic, we can still trace those three steps and if so, how. ${ }^{39}$ How do we get from onto-politics and geopower to politics and power? In discussion, Grosz has suggested that ' $[\mathrm{p}]$ ower-the relations between humans, or perhaps even between living things-is a certain, historically locatable capitalisation on the forces of geopower'. ${ }^{40}$ It is towards precisely this process of capitalisation that The Great Game draws us. The work is not concerned solely with the possible aesthetics of nonhuman entities, but also with the steps by which certain aspects of geopower are capitalised as power; with how nonhuman materials have been appropriated by humans, transformed and mobilised in their conflicts, even as their temporalities and spatialities stretch beyond and complicate them. It thus directs us back towards questions of the appropriation and capitalisation of nature, of techne and technology, capitalism and colonialism. As more earthly, ontological accounts remind us, this should not be reduced to the timespaces of recorded history: the conditions of possibility of The Great Game can be taken to imply specific climatic and terrestrial configurations allowing the domestication of animals and plants as well as subsequent innovations in craft and industry, design and production, all of which stand to be undone by earthly processes. While implicating the geologic, the planetary and the cosmic, however, The Great Game also asks viewers to consider moments within which certain groups of humans struggled to adapt to and co-opt earthly forces in schemes of expansion, domination and resistance.

In entraining and transforming a diverse range of materials, The Great Game thus invites attempts (however provisional) to trace through some of the steps between the forces of the earth, their actualization in specific forms and circumstances and their appropriation and instrumentalisation through manufacture and trade, occupation and insurgency. Highlighting interconnections between food, addictions, clothing, terrain, tactics and 
weapons, it embodies some of the complex material assemblages and imbrications of geopolitics. But, at the same time, it also asks us to consider the systems of signification and sense-making through which particular geopolitical entanglements are enacted, explained and understood. In hinting that geopolitics is driven, as Kathryn Yusoff's work suggests, by forces anterior and interior to the human, ${ }^{41}$ The Great Game also reminds us of the highly complex, cooperatively assembled, goal-oriented and knowledge-enabled technologies and practices through which humans have been able to constitute and exercise certain kinds of geopolitical power. In so doing, it questions resolutely earthly, materialist and affective philosophies that aim to locate the human entirely within 'nature'. This questioning becomes still more apparent when we consider the artness of the work.

\section{Artworks and worlds}

So far, we have considered the relevance of The Great Game to conversations about how we might link and move between the human and the earthly in our understanding of geopolitics. But the work is also suggestive in terms of how art itself has been conceptualised, bringing dualities (rather than dichotomies) between the material/representational and nonhuman/human further to the fore. The Great Game prompts us to question the ontology of art as well as geopolitics.

While critical narratives of art tend to concentrate on its allegedly disruptive, resistant or revelatory nature and effects, there is much less consideration of how and why the 'art' that is of interest should be considered 'art' at all (with art sometimes grouped with activism and other practices). ${ }^{42}$ More ontologically-oriented work, meanwhile, in emphasising its inhuman dimensions (for example in the Deleuzian idea of the artwork as a nonrepresentational bloc of sensation or affects and percepts), has tended to elide the contribution that practices such as fabricating, displaying, experiencing, appraising, selling, debating and theorising make to certain things (and not others) being considered art in the first place. What, then, should we consider specifically artistic about art; what might be overlooked in accounts of art as primarily earthly or affective; and what, in turn, is the significance of this for our take on geopolitics? Considering the ontology of art and how this takes shape through particular artworlds further returns us to the question of the human, both within, but also in some ways distinct from, the earthly.

Here we turn again to Grosz. She approaches art ontologically as 'the opening up of the universe to becoming-other ${ }^{43}$ and states that her goal is to develop a philosophy that is not 'confirmable by some kind of material 
evidence or empirical research' and which 'neither replaces art history and criticism nor claims to provide an assessment of the value, quality, or meaning of art'. ${ }^{44}$ This position holds in the ontologically-oriented discussions of art as that which intensifies sensation in the earlier parts of Chaos, Territory, Art and Becoming Undone, but it breaks down in later chapters, when she comes to discuss specific Western Australian aboriginal artists and artworks. Introducing Western Australian aboriginal art as a movement, in terms of its social, professional, political and economic contexts and functions, Grosz engages in the kinds of representational, historical, critical and judgemental discussion her earlier statements appear to foreclose.

As she states, this more empirically-oriented discussion is intended in part to distinguish her ontological purposes from more traditional art historical readings. But the two are not easily separated. Indeed the contextualising discussion is useful at an epistemological level, in that it reveals and clarifies the intentional, imaginative and interpretive dimensions of the works discussed as well as the role played by their artworld contexts in constituting them as 'artworks'. These are exactly the kinds of (largely anthropic) aesthetic and arthistorical contexts that are meant to be bypassed, but their inclusion is indicative of their utility in understanding actual artworks as such. ${ }^{45}$ The further point here is that these contexts go towards constituting the ontology of artworks as complex and multiple, as nonrepresentational and representational, affective and intentional and that this complicates attempts to encompass them within an ontology of affect.

This has already been made evident to some extent in our discussion of The Great Game, in that we have stressed how the work both 'is' a war blanket using camouflage while also being 'about' it, in that it proposes an argument as to how camouflage may function both as a military-aesthetic technology and a metaphor for the relationship between elite-directed geopolitics and the public sphere. Similarly, Western Australian aboriginal art both 'is' a materialization of the earthly, but is also 'about' this, as Grosz's descriptions of artworks as artworks (that is: framed, titled, painted, explained, curated, exhibited, sold, debated etc.) indicate. And this ontologically perplexing combination of 'isness' and 'aboutness' is what has often been held to be characteristic of art, a condition that nonrepresentational or affective theories of art struggle to circumvent. ${ }^{46}$ This interplay between materiality and representivity runs through both the artworks and the artworlds within which the 'isness' and 'aboutness' of artworks happen. As with the contexts of Western Australian aboriginal art, it is useful to trace these for The Great Game, as this clarifies the situations within which and means whereby the work might be said to work. 
The creation of The Great Game, as with War Boutique's practice in general, stems from a number of connected developments. The first was the artist's decision to abandon a professional career in military/police textiles and clothing due to disgust with the invasion of Iraq. This was a decisive event that caused War Boutique to question their role in relation to the state, military, police and corporate activity. The second was the decision to enrol in art school (Goldsmiths in London): as well as a grounding in art concepts and tactics, an MA from a prestigious art school can facilitate and legitimise one's identification as an artist. ${ }^{47} \mathrm{~A}$ third concerns the entry of War Boutique's work into the art market: The Great Game was shown first in a commercial gallery that was also acting as dealer for the artist. ${ }^{48}$ In this context, the work can be linked to the growing market for appropriated militarist images and by the creative appropriation of camouflage in Western fashion since the 1990s. With several works bought by wealthy private collectors, War Boutique's creations have entered the art market as cool, desirable commodities. But although available in the art market, the potential public interest and significance of The Great Game has also recognised by its inclusion in the exhibition Caught in the Crossfire: Artistic Responses to Conflict, Peace and Reconciliation at the Herbert Gallery and Museum in 2013. Considering this exhibition further illustrates the role played by curatorial practices in providing new material/representational contexts for artworks. $^{49}$

In this exhibition, The Great Game appeared in a section titled 'The Machines of War', which was dominated by textile and sculpture and which focused on artistic fascination with weapons and bodily armour. This included works such as Al Johnson's series of guns with female names, Betty Mark 1, Betty Mark 2 and Sadie (n.d.), made from velvet and satin in a bright scarlet, which evoke forms of femininity not typically associated with weaponry. This placed The Great Game into a specific artworld context dealing with fabrics and the material enactment of politics, questioning and exploring the relationship between objects, their origins, and their uses (see Figure 4).

\section{[INSERT FIGURE 4 ABOUT HERE]}

In structural terms, The Great Game foregrounds British experiences and perspectives and places Afghanistan in the background. In Caught in the Crossfire, however, directly alongside the work was another textile piece that emerged from an earlier military conflict in Afghanistan, a rug made in the early 1980s, possibly by Baluchi people, which appropriates images of war machinery alongside more abstract designs. ${ }^{50}$ Designed in the form of a prayer 
rug with a niche (mibrab) to be placed in the direction of Mecca, the rug's motifs include helicopters, fighter jets, tanks and grenades. Stylised flowers and plants are used to fill the space between them. Afghan knotted rugs traditionally featured symmetrical and geometric designs in a muted, subdued palette, but this changed from 1979 when motifs relating to the Soviet invasion of the country began to appear. The terrain of Afghanistan can also be found in this textile, not only in the earthy, dusty tones but also in the materials themselves: made from the wool of that country, from animals living on that land, the rug is inherently a part of Afghanistan. However, tanks, grenades and other symbols of warfare suggest imperial conquest and a re-writing of the landscape.

Designed and intended for practical use, like the materials employed in The Great Game, the rug registers political events taking place around the textile makers, with conflict and invasion co-existing alongside religious practice. The rug, already part of the Afghan tradition of textile making, has thus been used as a means to report, to protest and to comment, with this example created during a particular moment when the everyday life of Afghans was disrupted by violence. This rug was very different to others (held within the British Museum rug collection) that were originally considered for exhibition, however. More recently produced rugs are more colourful and eye-catching, but this example was chosen precisely because of its subtlety and intended purpose. Moreover, the changing contexts in which Afghan war rugs operate also hold significance. The rug has become part of a wider tradition that has emerged through numerous conflicts in Afghanistan. As access to materials and markets has become more problematic, traditional textiles increasingly combine reportage with commodification: in a country repeatedly changed and disrupted by war, most rugs are now created specifically for export. The rug therefore exists in several registers simultaneously: a prayer mat, a work of reportage, a souvenir, a commodity. Yet such rugs are also caught up in their own entanglements of terrain, imperialism and trade - now primarily commodities, they exist as souvenirs and museum objects that document events for others and are much less part of a textile tradition specific to a region and people of Afghanistan. The curated context of the exhibition thus gives The Great Game subtly different resonances - both affective and semantic - from its exhibition in a commercial gallery, further demonstrating how works are constituted by institutions and practices as well as by their own representational/nonrepresentational dimensions. ${ }^{51}$

\section{Conclusion}


One strand of thinking on art and geopolitics approaches art as a mode of intervention in geopolitics; specifically, as a way of disrupting, hijacking or reorienting geopolitical discourses, visualities and imaginaries. But it is also possible to approach art as a form of onto-epistemological inquiry into the nature of geopolitics and our knowledge of it. Art connects the ontological and the epistemological with regard to geopolitics by posing questions as to what geopolitics is (for example in terms of its materiality, representivity or technicity) and as to how we can know it (via aesthetic vis-à-vis other modes of inquiry). We therefore support calls ${ }^{52}$ to engage more substantially with art and aesthetics as ways of furthering consideration of the human/posthuman and the representational/material, particularly in relation to questions of geopolitics. Art can push us to question theoretical trajectories and prompt their cross-fertilisation and rethinking. If debates about representationnonrepresentation, criticality-experimentality, humanism-posthumanism or materiality-discursivity risk becoming ossified and binaristic, art can bring life to them, not only because it is of materiality, but also because it sets materiality and representation in play with each other.

We have made our argument in part via the work of Arthur C. Danto, who argued that art and philosophy could be understood metaphorically in terms of the space between language and the world, where language is understood as being 'about' the world of which it is also a part. ${ }^{53}$ While emphasising the linguistic, the semantic and the human, therefore, Danto did not deny the nonlinguistic, the material or the nonhuman, but he did distinguish them and sought to understand their (frequently paradoxical) interrelations. While the critique of representationalism and work in the sciences continue to challenge our ideas of what representation is, it is still necessary to 'go through it'. ${ }^{54}$ The same is true of the category of the human. If art draws us towards a more-than-human understanding of geopolitics, it also pushes us to think about capacities and practices that appear to be distinctively human.

The challenge of how such issues are to be conceptualised, theorised and investigated remains at the heart of research and debates across the arts, humanities, sciences and social sciences. One of the more tricky problems from an ontological point of view is that distinguishing between the representational and nonrepresentational, the human and nonhuman can imply a bifurcated reality, between the human, representational, phenomenal and discursive and the nonhuman, nonrepresentational, noumenal and affective. ${ }^{55}$ We do not consider possible solutions to this here, but note that scientific and philosophical debates on the existence and nature of this bifurcation and its 
epistemological consequences continue to be unresolved. ${ }^{56}$ We have only touched on these debates, but they form the broader intellectual context within which we see the relationship between art and geopolitics as a generative site for geographical inquiry.

We have found The Great Game suggestive in these terms, but also more specifically with respect to the possible (geo)politics of art. This artwork encourages us to think of art and geopolitics as both earthly and anthropic, material and ideational, nonrepresentational and representational. We have also suggested that art is a suggestive field in which to think through the materiality of geopolitics while keeping questions of critique in view. But in developing such ideas, more thought is needed concerning the manner in which artworks are taken to be artworks. Much is at stake in this deceptively simple issue. Artworks take in material and semantic elements of the world and rework them. In the process, they become fragments of the world that are also about the world and it is in significant measure in the interplay between these two conditions that we see them as inviting the kind of thinking we have outlined here.

\section{Notes}

\footnotetext{
${ }^{1}$ See, for example, L. Amoore and A. Hall, 'Border theatre: on the arts of security and resistance' Cultural Geographies 17, 2010, pp.299-319; S. Graham, '10: Countergeographies' in Cities Under Siege: The New Military Urbanism (London: Verso, 2010) pp.357-385; A. Ingram, 'Experimental geopolitics: Wafaa Bilal's Domestic Tension' Geographical Journal 178, 2012, pp.123-133. J. Sundberg, “Trash-talk' and the production of quotidian geopolitical boundaries in the USA-Mexico borderlands' Social \& Cultural Geography 9, 2008, pp.871-90; A. Williams, 'Disrupting air power: performativity and the unsettling of geopolitical frames through artworks' Political Geography 42, 2014, pp.12-22.

2 E. Grosz, Chaos, Territory, Art: Deleuze and the Framing of the Earth (New York: Columbia University Press, 2008) and Becoming Undone: Darwinian Reflections on Life, Politics, and Art (Durham and London: Duke University Press, 2011); See also K. Yusoff, E. Grosz, N. Clark, A. Saldanha, C. Nash, 'Geopower: a panel on Elizabeth's Grosz's Chaos, Territory, Art: Deleuze and the Framing of the Earth' Environment and Planning D 30, 2012, pp.971-988. See also K. Yusoff, 'Geologic subjects: nonhuman origins, geomorphic aesthetics and the art of becoming inhuman' Cultural Geographies 22, 2015, pp.383-407. The possible nature of posthuman aesthetics is considered through art in D. Dixon, H. Hawkins and E. Straughan, 'Of human birds and living rocks: remaking aesthetics for post-human worlds’ Dialogues in Human Geography 2, 2012, p.253.
} 
${ }^{3}$ In our title and in what follows we borrow the term 'earthly' from Grosz. An alternative term, which signals 'forces' as well as 'materials', 'materiality' and the 'immaterial', might be 'elemental'. Another might be, 'Deleuzian'.

${ }^{4}$ For example, Brian Massumi writes: 'Ultimately, the thinking of speculative pragmatism that is activist philosophy belongs to nature', in Semblance and Event: Activist Philosophy and the Occurrent Arts (Cambridge MA: MIT Press, 2011). p. 28. ${ }^{5}$ In certain respects we therefore echo calls by Gillian Rose and Divya Tolia-Kelly and by Estelle Barrett and Barbara Bolt to approach, respectively, the visual/material and the representational/material dimensions in a similar way. G. Rose and D. Tolia-Kelly eds., Visuality/Materiality (Farnham: Ashgate, 2012); E. Barrett and B. Bolt, eds. Carnal Knowledge: Towards a "New Materialism" through the Arts (London: I.B. Tauris, 2013). ${ }^{6}$ A. Danto, 'The transfiguration of the commonplace' Journal of Aesthetics and Art Criticism, 33, 1974, pp.139-148. In art history, Duchamp's fountain (the urinal that is an artwork) is frequently seen as a defining instantiation of this duality. See for example, B. Groys, Art Power (Cambridge, MA: MIT Press 2008). While this duality is emphasised in conceptual art, Danto argues that it is intrisic to art more generally. 7 While many capacities once thought to be distinctively human have recently been identified in other species, this is also facilitating a refined understanding of how humans are uniquely able to mobilise, inter alia, fictive language, abstract symbolic cognition, 'third person' perspectives and fine motor control. See for example G. Hatfield and H. Pittman, eds. Evolution of Mind, Brain, and Culture (Philadelphia: University of Pennsylvania Press, 2013).

${ }^{8}$ For example in the later sections of Grosz 2008 and 2011.

9 A. Danto, 'The artworld', Journal of Philosophy 61, 1964, pp.571-584

10 A. Last, 'Fruit of the cyclone: undoing geopolitics through geopoetics', Geoforum 64, 2015, p56. See also A. Last, 'We Are the World? Anthropocene cultural production between geopoetics and geopolitics' Theory, Culture \& Society 2015, doi:10.1177/0263276415598626.

${ }^{11}$ On the importance of practices of representing and manipulating the material world, see I. Hacking, Representing and Intervening: Introductory Topics in the Philosophy of Natural Science (Cambridge: Cambridge University Press, 1983) and T. Ingold, The Appropriation of Nature: Essays on Human Ecology and Social Relations (Iowa City: University of Iowa Press, 1987).

${ }^{12} \mathrm{H}$. Hawkins, 'Dialogues and doings: sketching the relationships between geography and art' Geography Compass 5, 2011, pp. 464-78.

13 The essay considerably enlarges the scope and reach of the work and might be considered part of it as well as being 'about' it - such dualities are significant to our argument overall.

${ }^{14}$ Dixon et al., 'Of human birds and living rocks', p.253.

${ }^{15}$ See < http://www.warboutique.com/>.

16 War Boutique, 2011, 'The Great Game'. 
17 'The Great Game'.

${ }^{18}$ G. Hartcup, The War of Invention: Scientific Developments, 1914-18 (London: Brassey's Defence, 1988).

${ }^{19}$ I. Forsyth, 'Subversive patterning: the surficial qualities of camouflage' Environment and Planning A, 45, 2013, pp.1037-1052; see also I. Forsyth, 'Designs on the desert: camouflage, deception and the militarization of space', Cultural Geographies, 21, 247265.

${ }^{20}$ H. Blechman and A. Newman, Disruptive Pattern Material: An Encyclopaedia of Camouflage (London: DPM Ltd, 2004).

${ }^{21}$ UK Ministry of Defence, 'New Afghanistan camouflage design unveiled', 2009, $<$ http://www.defencetalk.com/new-afghanistan-camouflage-design-unveiled23497/\#ixzz2hoLjjwnT>.

22 'The Great Game'.

${ }^{23}$ J. Protevi, Political Affect: Connecting the Social and the Somatic Minneapolis: University of Minnesota Press 2009).

${ }^{24}$ M. Yapp, 'The legend of the Great Game' Proceedings of the British Academy 111, 2001, pp.179-198.

${ }_{25}$ McIntosh Patrick (n.d.) TACTICAL DECEPTION- Dean Gallery GMA A64/1/16/4/3/1.

26 'The Great Game'. This question is taken up in the academic, journalistic and art work of Trevor Paglen. T. Paglen and R. Solnit, Invisible: Covert Operations and Classified Landscapes (New York: Aperture 2010).

${ }^{27}$ In email correspondence, War Boutique refers to Slavoj Žižek, who writes, 'Systemic violence is ... something like the 'dark matter' of physics, the counterpart to an all-too visible subective violence. It may be invisible, but it has to be taken into account if one is to make sense of what otherwise seem to be 'irrational' explosions of subjective violence'. S. Žižek, Violence (London: Profile 2009), p. 2.

${ }^{28}$ See for example, A. Barry, 'The Translation Zone: Between Actor-Network Theory and International Relations' Millennium - Journal of International Studies 41, 2013, pp.413429; A. Barry, Material Politics: Disputes along the Pipeline (Chichester: Wiley-Blackwell 2013); K. Meehan, I. Shaw and S. Marston, 'Political geographies of the object' Political Geography 33, 2013, pp.1-10; J. Sundberg, 'Diabolic Caminos in the desert and cat fights on the Río: a posthumanist political ecology of boundary enforcement in the United States-Mexico borderlands' Annals of the Association of American Geographers 101, 2011, pp.318-36; V. Squire, 'Desert 'trash': posthumanism, border struggles, and humanitarian politics' Political Geography 39, 2014, pp.11-21. W. Walters 'Drone strikes, Dingpolitik and beyond: furthering the debate on materiality and security' Security Dialogue 45, 2014, pp.101-18.

${ }^{29}$ M. De Landa, A Thousand Years of Nonlinear History (New York: Zone Books 1997).

${ }^{30}$ Grosz, Chaos, Territory, Earth and Becoming Undone and Yusoff et al, 'Geopower'.

${ }^{31}$ Grosz, Chaos, Territory, Earth, pp.2-3. 
${ }^{32}$ De Landa, $A$ Thousand Years, p.21.

${ }^{33}$ Kathryn Yusoff discusses the nonlocal, nonhuman dimensions of subjectivity in 'Geologic subjects', 2015.

${ }^{34}$ In Yusoff et al., 'Geopower', p.988.

${ }^{35}$ Clark in Yusoff et al., 'Geopower', p.976.

${ }^{36}$ Clark in Yusoff et al., 'Geopower', p.976.

${ }^{37}$ Clark in Yusoff et al., 'Geopower', p.976.

${ }^{38}$ Grosz Chaos, Territory Earth, p.3.

${ }^{39}$ Saldanha, in Yusoff et al., 'Geopower', seems to raise a similar kind of question.

${ }^{40}$ Grosz in Yusoff et al., 'Geopower', p.975.

${ }^{41}$ Yusoff, 'Geologic subjects'.

${ }^{42}$ For example in Graham, 'Countergeographies'.

${ }^{43}$ Chaos, Territory, Earth, p.23.

${ }^{44}$ Chaos, Territory, Earth, pp.1-2.

${ }^{45}$ Danto's essays 'Transfiguration' and 'The artworld' are classic statements on the importance of intentionality, representation and institutional and discursive contexts in constituting artworks as art.

${ }^{46}$ See for example, C. Lotz, 'Representation or sensation? A critique of Deleuze's philosophy of painting' Symposium 13, 2009, pp.59-72. While Massumi sees the representational in art as deadening of creativity and thus apolitical, Boris Groys and Jacques Rancière emphasise the importance of the interplay between the material, affective or nonrepresentational and the representational to modern and contemporary art. Groys, Art Power, J. Rancière, Dissensus trans. Steve Corcoran (London: Continuum 2010).

${ }^{47}$ We cannot know whether such considerations apply to the cave and rock paintings discussed by Yusoff, 'Geologic subjects'. But as she discusses, their entry into 'art history' in the mid-twentieth century was shaped by political stances in relation to the Holocaust and the atomic bombings of Hiroshima and Nagasaki.

${ }^{48}$ See <http://andipa.com/artist/war-boutique>.

${ }^{49}$ Here our writing shifts into a more curatorial register.

${ }^{50}$ The rug is part of the British Museum collection, BM 2030, 6013.11.

${ }^{51}$ The Great Game work was subsequently acquired by the National Army Museum in London. <http://www.nam.ac.uk/collection/collection-news/great-game-175-yearsafghanistan>.

${ }^{52}$ Dixon et al., 'Of human birds and living rocks'.

${ }^{53}$ Danto, 'Transfiguration'.

${ }^{54}$ S. O'Sullivan, after Deleuze and Guattari, in Art Encounters Deleuze and Guattari:

Thought Beyond Representation (Houndmills: Palgrave Macmillan, 2006), p.16.

${ }^{55}$ On the problem of a bifurcated reality see P. Gratton, Speculative Realism: Problems and Prospects (London: Bloomsbury, 2014); see also S. Shaviro, Without Criteria: Kant, Whitehead, Deleuze and Aesthetics (Cambridge MA: MIT Press, 2009). 
${ }^{56}$ In philosophy, see Gratton, Speculative Realism. For a summary of debates in the neurosciences and psychology as well as a critique of 'affect without a subject', M. Wetherell, Affect and Emotion: A New Social Science Understanding (London: Sage, 2012). Overviews of relevant developments and debates in cognitive science are provided by R. Wilson and L. Foglia, 'Embodied cognition', in Stanford Encyclopedia of Philosophy (Stanford: Metaphysics Research lab 2011)

$<$ http://plato.stanford.edu/entries/embodied-cognition/> and L. Shapiro, 'Embodied cognition', in E. Margolis, R. Samuels, S. Stich, The Oxford Handbook of Philosophy of Cognitive Science eds. <DOI:

10.1093/oxfordhb/9780195309799.013.0006>. 